\title{
Health-Promoting Managerial Work: A Theoretical Framework for a Leadership Program that Supports Knowledge and Capability to Craft Sustainable Work Practices in Daily Practice and During Organizational Change
}

\author{
Lotta Dellve ${ }^{1, *}$ and Andrea Eriksson ${ }^{2}$ \\ 1 Department of Sociology and Work Science, Gothenburg University, 40530 Gothenburg, Sweden \\ 2 School of Technology and Health, KTH Royal Institute of Technology, 14157 Huddinge, Sweden; \\ andrea.eriksson@sth.kth.se \\ * Correspondence: lotta.dellve@gu.se; Tel.: +46-31-786-4018 \\ Academic Editor: Kristine Crondahl \\ Received: 9 February 2017; Accepted: 28 April 2017; Published: 5 May 2017
}

\begin{abstract}
The aim of this article is to describe a theoretical framework, i.e., theoretical underpinnings and pedagogical principles, for leadership programs that support managers' evidence-based knowledge of health-promoting psychosocial work conditions, as well as their capability to apply, adapt, and craft sustainable managerial work practices. First, the theoretical framing is introduced, i.e., a system theory that integrates key work conditions with a practical perspective on managerial work and organization. Second, pedagogical principles and measures for leaders' training in integrated handling across system levels are described. Last, we present summarized results from an intervention study applying the theoretical framework and pedagogical principles. The complexity of interactions among different factors in a work system, and the variety in possible implementation approaches, presents challenges for the capability of managers to craft sustainable and health-promoting conditions, as well as the evaluation of the program components. Nevertheless, the evaluation reveals the strength of the program, in providing holistic and context-sensitive approaches for how to train and apply an integrative approach for improving the work environment.
\end{abstract}

Keywords: Leadership; training; health promotion; system theory; managerial work; sustainability

\section{Introduction}

Over the past three decades, managers of public organizations in the social welfare sector have struggled to handle important policy and organizational changes to reduce costs and develop better quality of service [1]. However, the work environment in public organizations has also become more challenging; for example, both the work demands and the rates of turnover among workers have increased during recent years in Sweden [2]. There is also strong reason to believe that deteriorating psychosocial working conditions are among the main contributing factors to an increased prevalence of sick leave [3,4] and occupational disorders, both in Sweden and in other European countries [5]. Work-related diseases, and especially mental health problems due to organizational and social conditions at work together, comprise the main reasons for occupational disorders and high frequencies of sick leave [4]. This is a problem for the individual, the organizations, and also for society. High turnover rates have serious implications for the continuity, quality, and stability of services, and could also damage organizational performance [6]. 
Studies of sustainable organizational developments point to the importance of a management approach that integrates the perspectives of effectiveness and quality of performance with the development of beneficial working conditions [7-9]. Sustainable work systems have been defined as the interaction between dimensions of intentions and the handling of actors, and social and cultural conditions. Each dimension and the interaction between the dimensions, are important for function, well-being, and capability within all levels (individual, group, and organizational) [9]. The concept of sustainable work systems aligns with the Ottawa Charter's principles of health promotion (1986), which emphasize that health is interrelated with our living conditions, including our working conditions, as well as that health is a critical resource for social, economic, and personal development. Thus, health-promotive perspectives at the workplace focus mainly on work resources that support employees and their managers in maintaining and improving their health, achieving their work goals, and developing personally, as well as handling significant risk factors and conditions [10].

High-quality leadership is considered to be a key condition for organizing better health-promoting working conditions [10-13]. The most important factors and conditions for improving workers' health, well-being, and engagement have been identified through literature reviews $[4,11,12,14,15]$, and the evidence-based knowledge is rather robust. However, the interactions between individuals, groups, and organizational factors have often of stronger magnitude than single factors $[13,16]$. Therefore, managerial work based on the knowledge of how to handle the interactions of multi-component factors and conditions across organizational levels, is crucial for sustainable development. Managers also need organizational preconditions, competence, and strategies for meeting challenges in complex social and organizational working conditions, as well as for taking leadership in building the capacity for more sustainable working conditions [17-19]. This was also recently acknowledged by regulations in the Swedish Work Environment Authority (2015: 16).

The interrelated factors associated with sustainable health imply that leadership programs which focus on building job resources and health-promoting conditions should be based on more holistic theories of sustainable working conditions. System theory requires the holistic consideration of factors, conditions, and relationships between individual challenges in the context of conditions at home and in the workplace (micro-level), within the rules, systems, norms, and values of the organization (meso-level), and with regard to impacts from society (macro-level) [20]. System theories have been developed in many nearby fields, e.g., ergonomics and human factors [21], and occupational health [22], to establish, support, and maintain healthy environments, acknowledging the interconnectedness between individuals, the workplace, and organizational and societal conditions. Recently, Bone (2015) applied the socio-bio-ecologic model of Bronfenbrenner (1999) to occupational health, to support a broadened view of workplace well-being. Her model [23] was complemented with the chronosystem level, i.e., focusing on time aspects including developments over time that may start at one level, but have implications for all levels.

However, managers operate in a day-to-day world that is often far from theoretical ideas and models, and they face many difficulties in translating, interpreting, integrating, and actually implementing regulations and health objectives. This may explain why managers struggle with developing managerial practices that support sustainable work conditions $[17,18,24]$, despite years of occupational and public health research, which has identified the most important factors constituting risk for negative health outcomes across occupations and countries [4,15]. Therefore, we applied more practical perspectives of managerial and institutional work in the development of a program that supports managers' knowledge and capability to craft sustainable work practices while also taking their own work situation into account. Inspired by Bone's (2015) application [23], we further developed the chrono-socio-bio-ecological model with a practice and handling perspective on managerial work and organizing [24-26], and applied the model to focus on health-promoting and sustainable leadership. The model forms the theoretical framework for the leadership program. 


\section{Aim and Disposition}

The aim of this article is to describe a theoretical framework, i.e., theoretical underpinnings and pedagogical principles, for leadership programs that support managers' evidence-based knowledge of health-promoting psychosocial work conditions as well as their capability to apply, adapt, and craft sustainable managerial work practices.

First, we describe the theoretical development and framework around system theory that integrates key work conditions, and introduces a practice perspective on managerial work and organization. Pedagogical principles and measures for integrated handling over different system levels are also described. Last, we describe an intervention study applying the theoretical framework, and present the summarized results.

\section{Development of a Theoretical Framework and Leadership Program}

In 2006, the first version of a health-promotive leadership program was developed in an intervention study focusing on leadership capacity for building health-promotive working conditions [13]. The program emerged from an interactive process between researchers and practitioners (human resource partners and operational managers from a wide range of human service businesses), based on evidence-based knowledge and close-to-practice challenges for managers when approaching health-promoting leadership. In 2008, the program and the materials were updated in collaboration with human resources (HR), occupational health services (OHS), and operational managers from companies in the private sector. The working material provided a systematic approach for working with complex issues of the work environment, and was developed in such a way that was applicable to managers in different kinds of human service organizations and industries, e.g., adding health-promotive perspectives at workplace meetings, and in systematic work environment management.

Leadership interventions based on the working material were implemented in different organizations, mainly in human service organizations, and in some private companies. In these, managers developed action plans for enhancing the work environment and health of their employees. Our own research on the implementation of these interventions showed that managers had increased their capacity for being health-promoting leaders who were better able to handle employees' health and healthy working conditions [27]. Also, self-rated health and work attendance had increased among their employees, as measured by employee questionnaires [28]. However, the health and working conditions of the managers themselves had not improved, and there were several indications of more stress, and stressful work conditions among managers [17-19,29,30], in addition to high turnover rates [31] for managers in the public sector. These challenges were often associated with the demands of organizational restructurings and continuous workplace changes [17,30,32]. Interviews with employers about opportunities to implement the leadership program elicited requests to integrate values of sustainable working conditions with other organizational values, such as leading change, and continuous improvements in efficiency and quality. Therefore, we complemented the program with health-promotive handling strategies and conditions for managers and managerial work during change management processes, in a new research project from 2013 to 2016. Updated evidence-based working material for the project was developed and launched in 2016.

The present version of the leadership program was developed in interactive processes involving researchers and practitioners (managers and partners from HR and OHS). This meant that the researchers developed the content of the working material by conducting literature reviews focusing on original empirical studies that were compared with published reviews; the working material was then refined through interactions with practitioners to focus on relevant issues for health-promotive managerial work. The objectives that guided the development of the working material were to: (1) Identify key evidence-based health-promotive psychosocial work factors and conditions for occupational health; (2) identify conditions and leadership strategies supporting sustainable change management; and (3) identify managerial practices and central conditions of importance to handle and 
effect sustainable changes. While the first two objectives were completed through literature reviews of the extensive multidisciplinary literature on workers' health and well-being, the last objective involved an iterative process based on literature reviews and continuous input from: (1) Elder-care managers (450 managers during 15 occasions) connected to the introduction of a leadership education program focusing on these issues; (2) external expert researchers and experienced partners from HR, through written feedback on the content of the material; and (3) 10 seminars with process leaders prior to the performance of interventions. Input on the content from managers and process leaders was also received during and after implementation of a leadership program based on the working material.

\section{System Theory Approach Integrated with a Practice Perspective on Managerial Work}

\subsection{The Model}

The theoretical underpinnings that we suggest for leadership interventions that support managers' knowledge of health-promoting conditions, as well as their capability to craft sustainable work, are derived from system theory approaches [20-23] in combination with theories of managerial and institutional work practices [24-26]. The system theory places the individual in the center, as the learning, understanding, and crafting of sustainable working conditions with respect to different system levels, contexts, and domains (work/home) starts with individuals' own reflections about their experiences and values. Likewise, recent theoretical developments in managerial and institutional work argue for bringing managers' sense-making, translation processes, bridging across levels, and handling strategies, back into studies of organizing and institutional theories [33]. In this context, this perspective can offer a more holistic understanding of the multi-components required for health and sustainability, when such components are sorted into system levels, and integrated with practice perspectives of managerial work and organizing practices, for crafting and bridging sustainability across systems and levels (Figure 1).

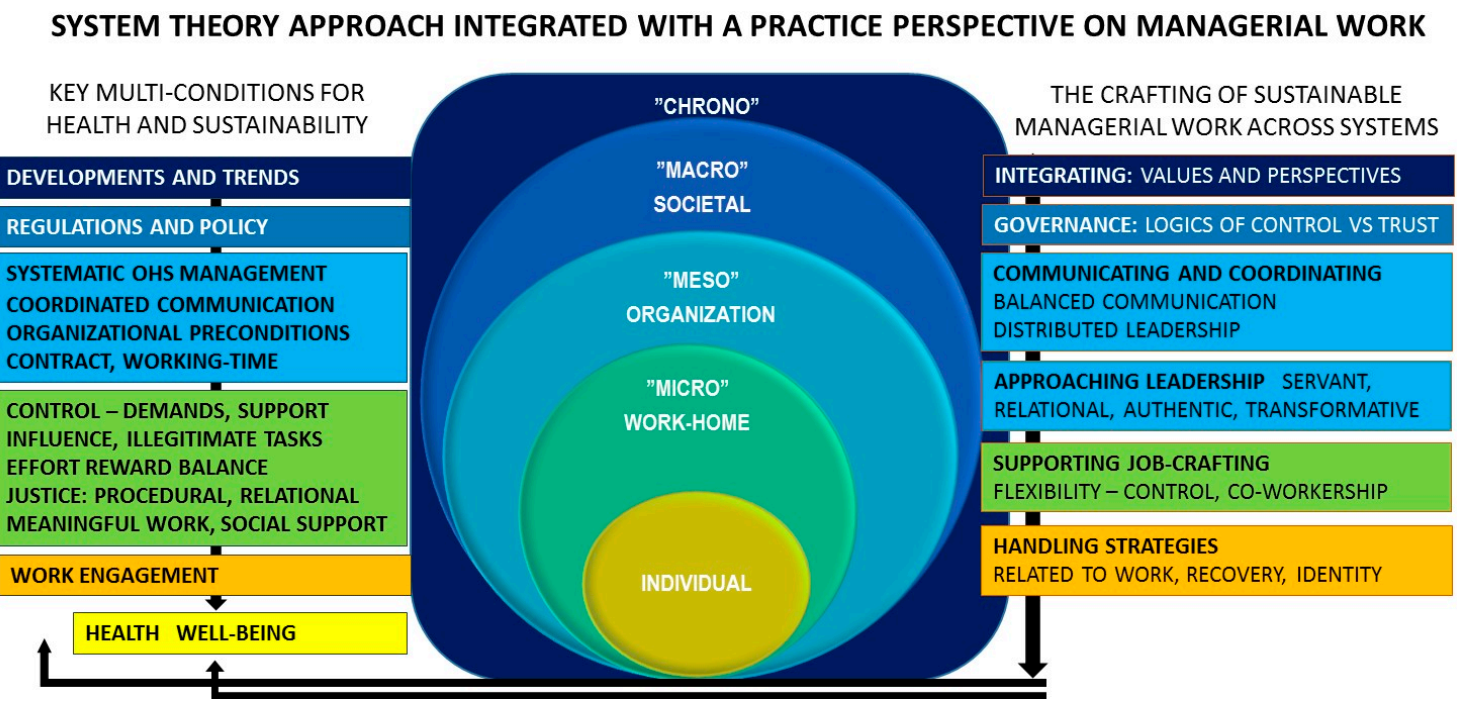

Figure 1. Theoretical framework of health-promotive and sustainable leadership, presented according to two highlighted perspectives: (1) The selected key conditions for health and sustainability; and (2) the crafting of sustainable managerial work across systems, applied to the chrono-socio-bio-ecological model. The arrows illustrate only the overall associations.

Despite knowledge of evidence-based risk factors and resources, there is a lack of comprehensive models of the mechanisms related to the crafting of healthy and sustainable working conditions. Moreover, managers' work and organization are the keys to bridging and handling the multiple components of risks and resource conditions for individuals and groups of workers over and within 
system levels [21-23]. In fact, managers who are actively bridging across organizational levels to integrate perspectives and serve core purposes (i.e., hybrid management) have had more success in sustainable organizational developments [17,18,32]. Besides, system theory on its own may not be enough to build leadership intervention programs, as it may fail to acknowledge the positive effect of interplays, bridgings, and crossings over systems boundaries. Therefore, we also applied a practical perspective on managerial work and organization; in this article we proposed a theoretical framework for enabling an understanding of the complex social practices of sustainable managerial work.

Some studies of institutional organizations have applied both the closer and wider perspectives that systems theories can offer. For example, Barley and Kunda (2001) argued for the importance of bringing work back into organizational research, i.e., focusing more on the work itself than on more abstract ideas of how organizations should look [34]. Ten years later, Lawrence and colleagues (2011) argued for bringing individuals back into organizational studies and institutional theory. They highlighted the importance of individual managers who actively interact with others (their social roles) in institutions, allowing for a substantial degree of freedom and choice in the interest of organizational capacity [33]. A system theory approach of managers' crafting can illustrate how proactive perspectives may come together in a positive feedback spiral, where leadership and organization support engagement and sustainable handling approaches, which in turn promote health and well-being, as well as organizational outputs [10,14,35].

Management is in practice often far-removed from theoretical ideas and organizational models, which is why more research into sustainable conditions would gain from more constructivist perspectives that are sensitive to context, and defined by the practical handling and organization of managers [24-26,33,36]. Thus, in this approach, holistic and multiple perspectives are taken into account to inductively build theories from close studies of managers' practice; analyses relate the data to contextual conditions. Studies with this perspective have gained insights from ambiguous, emergent, and unexpected activities and methods, through, for example, shadowing and interviews. Results from such studies in Scandinavia have described managerial work in public human service organizations in ways that include fragmentation, uncertainties, conflicts of values and loyalties, high-performance pressures, and often a hectic work pace and long working hours [17,18,24,25,29]. Accordingly, the work of managers has importance not only for their employees and the business, but also for their own sustainability. To craft health-promoting working conditions in normal circumstances, and also during organizational change, managers need knowledge and support in order to handle multiple interactions and combinations of multi-component risk and resource factors across different organizational levels [17,30,37,38]. From the perspective of sustainability, this includes work with health prevention and promotion, integrated with motivation, engagement, and organizational outputs [7,9,39]. Thus, leadership programs need to support the knowledge, awareness, and capability of managers that are related to the organization of sustainable psychosocial work conditions. Inspired by the practice perspectives of managerial work and organization [24,25], we applied this approach to the chrono-socio-bio-ecological model [23], and propose key conditions serving as mechanisms for crafting health-promotive and sustainable working conditions over system levels.

Key Conditions and Managerial Work that are Bridging across System Levels

Sorted into the levels of system theory, we here describe the identified key factors for health and sustainability, and thereafter the key conditions for crafting health-promotive and sustainable working conditions over system levels.

The individual level includes the job significance for the individual, i.e., the personal impact of the job on one's life, including the individual's capability, knowledge, demographics, attitudes, values, skills, behavior, lifestyle, self-concept, and health (mental, cognitive, physical). To support learning and application, all themes in the leadership program start with individual reflection of experiences, values, and well-being. Some of the central definitions related to health and well-being are reflected 
upon, to widen understanding and inspire further developments. These include health and well-being as a continuum, levels of satisfaction and happiness, sense of coherence and control over personal life [40-42] as well as being related to preferences of dwelling, and/or mobility and change [43]. Well-being also has an impact on other desired values related to sustainability, productivity, and quality in performance and work engagement [44]. Additionally, work engagement is considered to be both an important part of, and a condition for work-related health, as its status is strongly associated with health-related conditions, as well as efficiency and aspects of performance quality [45-47].

The crafting of individual-level sustainability focuses on the awareness of the individual, and handling strategies to improve job fit (i.e., the fit between individual values of work characteristics and those that are desired), as well as improvement of well-being, work balance/recovery, work climate, and engagement. Individuals use strategies to proactively deal with diminished resources (e.g., coping, recovery, selection, and optimization) and inter-role management (spillover vs. segmentation, inter-role conflicts) [48], and managers in their function use strategies to improve sustainable work conditions [49]. This work starts with the individuals or the managers themselves; acting to increase their awareness of their strategies, e.g., in order to improve time-management and control for recovery, and the support of employees [50,51]. Studies of managers in human service organizations have identified two major handling strategies: Actively accepting the situation by increased understanding and/or setting of boundaries of time and energy investments into the situation. Other strategies include working hard, prioritizing leisure time, and distancing oneself from identification with the managerial role $[30,32,50]$. In a prospective study, the most important support for the health-related sustainability of managers came from a better understanding of their role (not overly identifying with the managerial role, to give room for recovering leisure-time activities), and through the utilization of a private support network [38]. Approaching proactive acceptance based on an understanding of the complex situation, was associated with an improved quality of performance, and integrated development of various sustainable conditions. Setting boundaries was also important, especially if this was grounded on understanding [52].

Micro-level systems are settings and interpersonal relationships directly experienced by the individual workers/managers, and include the direct work environment, the workplace, and the work group. In this respect, several reviews have identified the most important psychosocial challenges for sustainable occupational health as being high job demand, lack of control, imbalance between effort and perceived rewards, poor support, organizational injustice (procedural and relational), and poor working climate $[4,5,15]$. Psychosocial resources within teams, and co-workership, are also significantly important for handling work challenges, i.e., social support, social climate, social capital, and sense of coherence $[5,15,49,53]$. Other important factors include control over one's work, meaningfulness, feedback, recognition, rewards, and development opportunities [5,14]. Evidence for general associations between mental health and reorganization is rather weak [8]. Organizational changes seem to have different implications for employees, some of whom are more resistant to change and some of whom are more vulnerable; this is why managerial work needs to consider and meet vulnerable individuals and groups based on their needs.

To improve job characteristics at the microsystem level, the concepts of job crafting [54] and job enrichment [10] can be applied to support employees' proactive handling of situations, i.e., increasing employees' autonomy over the planning and execution of their own work. This means that individuals can proactively optimize their work situation and redesign their work characteristics to fit their abilities and values, by the better use of resources, and adjustment of demands. When jobs are crafted and enriched, this in turn further enhances proactive handling, e.g., through improved rewards for the impact of their work [10,55], and through improved ownership for broader work goals. Thus, managerial work and organization to support employees' crafting of their jobs, implies both building in conditions that allow slackness and flexibility when possible, and smarter organizing to avoid over-work. Despite the necessity to leave space for individual job adaptation opportunities, organizing to support employees' recovery builds in time for reflection, develops standardized work processes 
when appropriate, adheres to orderliness to avoid extra work, and communicates goals and concrete goal levels to avoid uncertainties. It is also important to support work groups and teams in their collective work responsibilities, their autonomy and functioning, and their creativity and participation in development work $[35,53]$.

Meso-level systems are the organizational structures and company culture, such as the formal work organization, and social formations of communities. In this respect, a structured, systematic occupational health and safety management system, with activities and goals from health-promotive, preventive, and rehabilitation perspectives, is important for the prevention of employees' work-related injuries and diseases. These and other structural empowerment conditions are designed to decrease illness, but also increase influence and control, as well as delegate power and authority (i.e., enabling bureaucracy), of importance for both work satisfaction [10], and work attendance [56,57]. Likewise, can organizational preconditions support managers to better perform complex daily work practices in complex human service organizations? Recent studies have pointed to the benefit of a span of control not exceeding 30 subordinates [19], shared managerial assignments [35], and support through managerial groups, colleagues, and organizational resource functions (e.g., HR, communication) [38,52]. In addition, having reasonable working hours per week and an equitable employment contract [58] have significance for managerial sustainability.

Meso-level practice perspectives contain organizational practices related to norms, culture, management styles, and communication within the organization. One strategy is to design work and provide autonomy to enable individuals to proactively reduce job demands, and/or increase job resources. Other beneficial qualities at the meso-level include approaching leadership and communicating, which supports bridging across levels. Through our literature review, the following leadership approaches were identified as strongly associated with employees' health and work engagement across system levels: Servant leadership [59], authentic leadership [60], transformational leadership models, and more relation-focused leadership focused on positive leader-member reciprocal relationships that contributed to better job fit and work enrichment [61]. In the program, these were seen as inspiring the personal development of leadership approaches for managers, rather than providing fixed and framed models. Additional aspects of importance include balanced communication by managers to support active engagement [62], relational coordination to support information sharing around work processes, and distributed leadership to support participation in the wider meaning of the organization [63]. Together, these have major impacts as the mechanisms of managerial work that support sustainable conditions over different system levels.

Macro-level systems comprise the overall patterns of ideology that describe cultural or social context. These include public policy and politics that impact work and living conditions, the socioeconomic climate, and cultural ideologies, including the portrayal of the organization as presented by the media [32]. Workers may or may not be directly involved at this level, but regulations and practices may shape, influence, constrain, and/or strengthen the work characteristics [22]. Policies include regulations that aim to control and support the work environment, by interacting with structures in the microsystem, e.g., in Sweden, these include the regulation of the social and organizational work environment (AFS 2015: 4), and the Work Environment Act. The macro-system also defines the larger social system, e.g., social security, labor market conditions, and health care issues that are important for sustainable work [22].

Macro-level practice perspectives include societal governance reforms and approaches that serve or hinder crafting of sustainable conditions. For example, the governance of public organizations by logic of trust, which is characterized by serving core functions, and working close to the core business, seem to better support work engagement among employees than governance by logics of control $[35,64]$. Providing opportunities for employees/professionals to overview and participate in improvement work, as well as having influence over daily operations, might increase a sense of coherence and increased performance, even when major organizational restructurings are implemented. This close-to-practice perspective, despite operating at the macro-level, allows empathy 
with customers/clients, which encourages workers' effort and helping behavior [55], and appears to increase their work engagement [65]. While more controlling governance can create effectiveness in the short term, it can lead to exhaustion among employees in the longer term [35].

The chrono-level encompasses the dimension of times, trends and developments, as it relates to the work environment. Developments may be considered at the personal, workgroup, workplace, and organizational level. Positive but challenging changes can happen in "holding environments", which facilitate trustful conditions for developments when desired [66].

Chrono-level factors are used for sustainable development, through bridging levels and crafting sustainable working conditions, and are approaches for communication and integration of values and perspectives. Managerial approaches that integrate the perspectives of effectiveness, quality, and the work environment, have major importance for the long-term sustainability of changes in processes, for engagement, and for work integrity [7,67]. Integrating the values of professionals, administrators, customers, and leaders can be applied, for example, through dialogs in holding environments facilitating learning and increased awareness of values and perspectives connected to the work.

\subsection{Pedagogical Principles and Measures for Crafting Integrated Handling over System Levels}

An important point of departure when developing the leadership program was how to facilitate time-pressured managers to integrate evidence-based knowledge on improving employee health, into their daily leadership practice. It is claimed that managers gain limited learning outcomes from formal training programs, as individual participation in management programs rarely results in changes at the organizational level [68]. It is instead suggested that informal learning that relates to the skill development of managers, based for example, on social interactions and peer mentoring, has greater impact on managers' learning outcomes [69]. Furthermore, theories on adult learning generally stress the importance of personal reflection based on the learner's experience [70,71]. These types of theories include more specifically how individuals develop new insights and knowledge through critical analysis of previous knowledge, conceptions, and basic assumptions. The literature thus stresses the need to provide managers with learning materials and resources that enable them to reflect on knowledge that is based on their own situation and experience [72].

Furthermore, managers from the public sector express a need for, and value the support of peers, as the managerial role is often perceived as a lonely and challenging one [17,30]. Thus, an important basis of the leadership program is the dialogue-based meeting; this includes the sharing of reflections and experiences related to health and development within the work environment (Table 1).

An important principle for the development of interventions was research focusing on interactions among individuals and groups, and organizational risks, especially resource factors that have stronger effects than those of single factors $[13,16]$. This is acknowledged in the Job-Demand-Resources model [14], and we thus propose that this model can be applied from organizational and individual perspectives (meso- and microsystems) within interventions aimed at developing sustainable and health-promoting work conditions (Figure 2).

In this context, organizational perspectives mean the building of a capacity for sustainable conditions that correspond to the average needs of as many individuals as possible. The approach includes developments within the work environment that are integrated with efficiency and quality improvements, i.e., sustainable organizational developments $[7,9,67]$. Building a capacity for sustainable conditions means developing those resources that contribute to an organizational capacity to deal with demands within the organization [73,74]. These resources include creating generally good working conditions and a learning climate, systematized health and occupational management, integration of important values and norms into daily management, and communication that supports improvements, coordination, and the building of trust between individuals and across organizational levels. 
Table 1. Pedagogical ideas of interventions based on an analysis of needs of individual managers for support in developing health-promoting and sustainable work conditions.

\begin{tabular}{|c|c|}
\hline $\begin{array}{l}\text { Analysis of Needs of } \\
\text { Program Interventions }\end{array}$ & Pedagogical Principles of Program \\
\hline $\begin{array}{l}\text { Evidence-based knowledge on } \\
\text { the most important factors for } \\
\text { employee health as well as } \\
\text { leadership strategies for } \\
\text { improving employee health }\end{array}$ & $\begin{array}{l}\text { - Provision of course material on theories and research about } \\
\text { leadership strategies for improving employee health } \\
\text { External process leaders facilitating structured } \\
\text { dialog meetings } \\
\text { - } \quad \text { Reflections on own role for employee health } \\
\text { Exercises supporting managers' development of systemized } \\
\text { improvements of the most important health and work } \\
\text { environment issues at their workplaces }\end{array}$ \\
\hline $\begin{array}{l}\text { Managers' need for support in } \\
\text { leadership role }\end{array}$ & $\begin{array}{l}\text { - } \\
\text { - } \quad \text { Supportunities for managers to support each other } \\
\text { - } \quad \text { Reflections on perceptions and potential developments of } \\
\text { leadership role } \\
\text { - } \quad \text { Reflections on how managers themselves can balance their } \\
\text { work engagement and strategies for recovery }\end{array}$ \\
\hline $\begin{array}{l}\text { Managers' need for support in } \\
\text { implementing and adapting } \\
\text { program knowledge into their } \\
\text { operative context }\end{array}$ & 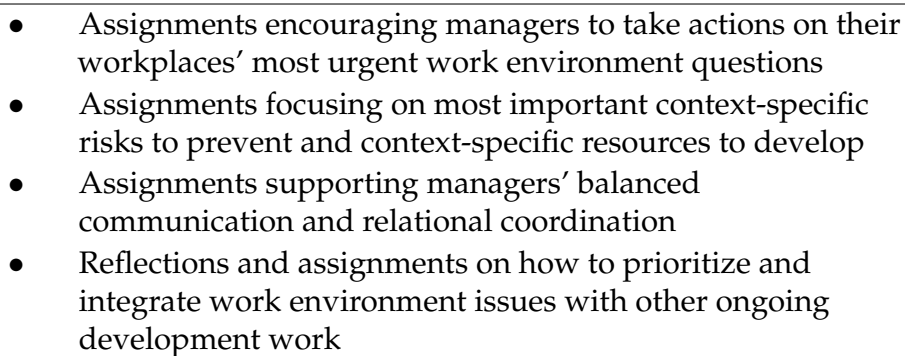 \\
\hline
\end{tabular}

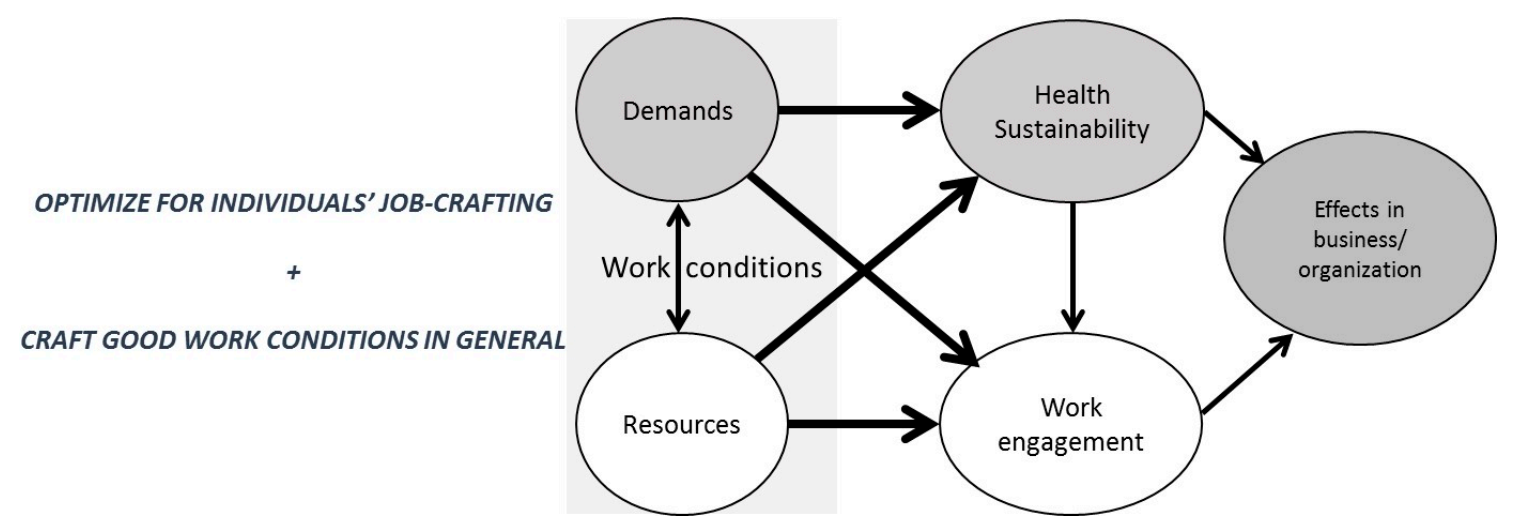

Figure 2. Application of the Job-Demand-Resource model [14], from individual and organizational perspectives.

The individual perspective in this context means the support of individual crafting of resources and demands [54,75]. This could mean supporting the development of individual handling strategies for work and recovery, supporting their adaptation of demands, and optimizing individual resources to fit the individual's capability and ambition.

The specific measures for supporting integrated handling of risks and resources over system levels were:

A. Take action from available individual and organizational resources: Increase awareness, support integrated knowledge, and act from available resources by (a) observing, identifying, acknowledging, delimiting and/or reducing risks and obstacles, and (b) supporting resources [76,77]. Resources at the individual level comprise using experiences, awareness, 
and handling strategies to shift between helicopter and close-up perspectives. At the group level, these comprise the group climate, communication, and social capital. Organization-level resources may include basic structures for OHS, organizational values, norms, communication, and governance.

B. Learn a model of dialog: Improve interactions, reflections, sharing, and practical applications of knowledge through dialog from the principles of balanced communication [62].

C. Improve the likelihood of change: Meet in shared understanding of the "why" and the vision of desired improvements, through continuous communication, and a stepwise change approach that supports assessment, continuous information, and supportive leadership [78]. Improving the likelihood of change also requires a practice-serving focus that supports engagement, authentic communication, and meta-learning over organizational levels for clever applications and adjustments to practice $[35,59,60]$.

Reflection assignments include reflecting on perceptions of and potential developments of participants' own leadership practices, as well as on how to lead sustainable development work. Helping managers to make change happen, and to take the lead in sustainable development work includes providing methods and assignments that in systematized, coordinated, and context-sensitive ways, support managers in meeting resistance, diminishing the most important risk factors for ill health, and focusing on how to enhance resources for health at the individual, group, and organizational level. Research supports the idea that managers' degree of dialog and participatory leadership within their workplaces is critical for the development of health-promoting and sustainable work conditions [79]. The program thus includes the development of relational coordination [63], i.e., building conditions for frequent, specific, and timely communication that is oriented toward building good relations and working toward common goals. The program also focuses on the manager's application of balanced communication when leading development work, including balanced communication between a work group's needs and goals and external needs and perspectives (Other-Self), and between open inquiry, acknowledging different points of view in the work group, and advocating management stances and decisions (Inquiry-Advocacy) [62].

\section{An Intervention Study Based on the Theoretical Framework}

\subsection{Method: Form, Participants and Evaluation of Intervention Study}

An intervention study applying the theoretical framework was performed over the time period of 2014-2016. This meant that a leadership training program was implemented and evaluated. The training program was structured into six group meetings, and participants were managers and key actors from the health care sector (Table 2). The model presented in Figure 1 describes the selected parts of the content of the meetings in the training program, to be reflected on, translated, and adapted to the various settings of the participants. Each theme in the meetings focused on key factors at each system level, and how these could be improved by specific managerial measures bridging over the system levels. Each theme included a brief description of important theories and summaries of recent evidence-based research about leadership, work environment, and health, as well as dialog questions and exercises to support managers' reflections, applications, and adjustments into their own managerial work practice. The meetings were led by two process leaders from HR and/or OHS, whose roles were to introduce themes and topics, to trigger and facilitate dialogue, discussions, and reflections, to assist managers in adapting to and applying the content of the interventions to the environment and health issues relevant to their workplaces.

The interventions included 31 first line managers, 13 second line managers and 21 organizational key actors and involved in total ten different process leaders. The evaluation was conducted through qualitative and quantitative methods. Sixteen qualitative interviews and three focus-group interviews with 28 organizational key actors, process leaders and participating managers were performed. The qualitative interviews contained questions on how the participants perceived the content and 
form of the training program, the hindering and facilitating factors within the content of the program in practice, as well as what parts of the program the managers had implemented at their workplaces.

A questionnaire detailing managerial challenges (e.g., working conditions), resources (e.g., organizational support), leadership approaches (e.g., structured and communicative leadership approaches) [80], and outcomes of the interventions was distributed to participating managers before the intervention, and again at the five and nine month post-intervention period (37, 27 and 24 managers answered the baseline, the first and the second follow-up, response rate being 86-100\%). Questionnaires were also distributed to subordinates of the managers who participated in the interventions (346, 293 and 193 employees answered the baseline, the first and the second follow-up, response rate $62-72 \%$ ); the main results from these questionnaires are presented in a research report [81].

The analyses presented in this paper focus on participants' perceptions of the form and content of the interventions, and conditions that affected the results of those interventions. The study was approved by the Central Ethical Review Board at Karolinska Institutet, Stockholm, Sweden (EPN 2014/1883-31/5).

Table 2. Descriptions of the six interventions performed within the research project; participants, number and type of participating workplaces/businesses, and type of educational form for the intervention.

\begin{tabular}{ll}
\hline Participants & Number and Type of Workplace/Business \\
\hline $\begin{array}{l}19 \text { first-line managers and key actors } \\
\text { (e.g., safety representatives and headmen) }\end{array}$ & 10 workplaces in a county council, majority hospital units \\
\hline $\begin{array}{l}15 \text { first-line managers and key actors } \\
\text { (e.g., safety representatives and headmen) }\end{array}$ & 8 workplaces in a county council, majority hospital units \\
\hline 6 first-line managers and coordinators & 3 workplaces within dental care \\
\hline $\begin{array}{l}9 \text { second-line managers and key actors from } \\
\text { a sector management group }\end{array}$ & 1 business area within elder care in a municipality \\
\hline $\begin{array}{l}5 \text { second-line managers } \\
10 \text { first-line and one second-line manager in } \\
\text { a management group }\end{array}$ & Varying medical businesses within a county council \\
\hline
\end{tabular}

\subsection{Summarized Results from Evaluation}

The results from the surveys showed that a majority of the participating managers perceived that the interventions had impacted their leadership (69\%) and developmental work (59\%) to some extent. Participants reported a significant increase $(p$ value $=0.04)$ in their competence regarding psychosocial work environment issues, directly after the interventions. In the qualitative interviews, managers noted that the pedagogical form of the interventions, i.e., reflective forms of dialog, after being provided with the knowledge and inspiration to structurally focus on positive health factors in the performance of daily work. Managers described the content of the leadership program as comprehensive and relevant, giving them broader perspectives and concrete tools for working with health promotion and prevention:

"Through reflections and discussions, I have become more conscious on my way of leading and how it can have consequences on employee health."

"Learnings from the leadership program include structures in health-promoting work. You can find a structure, you can use a structure with health promotion, not just small pieces here and there like fitness measures, but more a holistic view of how we can work [with health promotion]."

Analysis of the results from the pre- and post-intervention surveys showed that the managers also reported a significant increase in executing structured leadership with their subordinates directly after 
the interventions, and tended to note an increase in executing communicative leadership practices. A multilinear analysis model showed that an increase in communicative leadership practice had importance for managers' increased ratings of improvements in the psychosocial work environment $\left(r^{2}=0.22, p\right.$ value $\left.<0.05\right)$ and improvements in work planning $\left(r^{2}=0.31, p\right.$ value $\left.<0.01\right)$. Managerial subordinates who participated in the program also reported a significant increase in dialogue regarding the psychosocial work environment at the workplace over time ( $p$ value $<0.01$ ), as well as improvements in the psychosocial work environment ( $p$ value $<0.05)$.

Managers expressed in interviews that they prioritized coming to the intervention meetings, and that the support, encouragement, and inspiration that they received from peer managers was a highly valued component of the interventions; this was confirmed in post-intervention surveys, which pointed to significantly increased perceptions of support from peer colleagues. Overall, managers also reported increased organizational support after participating in the interventions $(p$ value $<0.01)$. Overall, work satisfaction increased over time among participating managers ( $p$ value $<0.01)$. A multilinear analysis model showed that an increase in support from peer managers $(p$ value $<0.05)$ and an increase in organizational support $(p$ value $<0.05)$ were to some extent important $\left(r^{2}=0.39\right)$ for increased work satisfaction among managers.

The degree of success of the six intervention groups differed from each other, and some intervention groups were more successful than others in implementing components of the theoretical framework of health-promotive and sustainable leadership. The qualitative evaluation of the implementation interventions showed that aspects related to relational coordination, i.e., contacts, network, and relations among different organizational levels, were critical for the success of the interventions. Interviews with the organizational stakeholders revealed that the interventions succeeded to a greater extent if top management had been actively creating structures for supporting and facilitating managers' engagement in workplace health-promotion activities. This meant, for example, that the work organizations that had been developing strategies consciously over a longer time on how to achieve a health-promoting workplace, that different kinds of measures and types of education in workplace health promotion had previously been offered to managers, and that adequate resources had been set aside for the engagement of OHS in workplace health-promotion measures directed toward managers. Further factors for successful implementation of the interventions were a good and functioning collaboration at different organizational levels between HR and OHS departments, and managers. Finally, qualitative interviews indicated that a critical success factor for implementation was the managers' own clear prioritization to set aside time to work according to the principles of the program at their own workplace. Moreover, the choice to start with those aspects of the program that were perceived as most urgent and/or important for their own workplaces was critical in determining the extent to which managers in interviews described that they adhered to the principles of the program in practice.

\section{Discussion}

This paper has presented a theoretical framework for a leadership program that supports the building of managers that are capable at bringing health-promoting and sustainable psychosocial work conditions to their managerial work practice. Results from an evaluation of the program, related to the theoretical framework, showed some of the strengths of such a comprehensive framework that allowed managers to adapt to their work context.

The psychosocial challenges that managers face, share important features with "wicked problems," i.e., notably high levels of social complexity, uncertainty, and divergence of values. For example, small changes that were not noticed in evaluations, may have contribute to changes in the whole system. We believe that a theoretical framework from a more holistic perspective can help develop a more comprehensive understanding of the working conditions that contribute to dramatic increases in mental health disorders, and that this also can be a foundation for crafting more health-promotive and sustainable conditions. System theory approaches in recent years have produced new and promising 
conceptualizations for understanding and handling occupational health challenges [21-23]. However, a system theory on its own may fail to acknowledge the positive effect of crossing system boundaries. Therefore, the practical perspective on managerial work and better organization supports the ability to adapt, adjust, and craft sustainable work conditions across these boundaries. This application is also in line with the Ottawa Charter's principles of health promotion, which emphasize the interrelatedness between health, living, and working conditions, as well as the critical resources for social, economic, and personal development. Studies of successful organizational improvements also point to the importance of a management approach that integrates the perspectives of effectiveness and quality, with the development of beneficial working conditions [7,8,35,67].

A couple of methodological aspects are important to consider. The evaluation, as well as inputs during the interactive approach in the development of the program, indicated benefits, but also challenges. In qualitative evaluations, participants reported that a strength of the program was that it gave a holistic presentation of how to apply an integrative approach to the work environment. Qualitative analysis also showed that one success factor for the implementation of interventions included a manager's choice to start with those parts of the program that were perceived as most urgent and/or important for their own workplaces. This meant, however, that there was a variation of approaches in how managers adopted and implemented parts of the program. The variety in implementation approaches created challenges for evaluating the components of the program empirically. Overall, it is difficult to apply the leadership program as an explanatory model for sustainable changes in the work environment and health, because it requires an extensive scope of details related to contextual factors that interact with developing the implementation process [82]. The iterative and interactive approach in our intervention study, involving close collaboration between researchers and practitioners, can be seen as a strength and a success factor for the implementation of the leadership program, as it has involved continuous dialogue on, and adaptation to critical contextual factors.

An important criteria for success in the development of capability in participating managers, is the individual motivation of participants to challenge existing preconceptions and work practices [83]. Another important issue for the outcomes of interventions based on the leadership program is enabling a learning environment within the managers' organizations that includes an interplay between the individual manager's readiness for change, and the work demands, work content, and responses of employees and upper management [84].

To support the transfer of the model and the leadership program across sectors and countries, evidence-based research of key factors and components has been included. However, research related to the practice perspective of managerial work and organizing has mainly been developed from studies in Scandinavian contexts, where there are advantages of accessibility to firms to do such research (e.g., through observations, case studies, shadowing, and interviews). Thus, the fieldwork tradition is very strong in Scandinavian research $[24,25,36]$. Additionally, this leadership program was implemented in a Swedish context, and further development, implementation, and evaluation in collaboration with researchers and practitioners from other countries would contribute to developing a leadership program that is valid within an international context.

Although a growing amount of research points to the importance of leadership for employee health and capability, research on leadership training interventions as part of developing occupational health and safety has so far been scarce [5]. We have developed a leadership program that showed positive effects at participating managers' workplaces [81]. However, evaluations of the program have been covered up to the six-month post-implementation period. More long-term workplace outcomes and learning processes following interventions would be of interest for gaining knowledge on the design of a leadership program that could contribute to sustainable outcomes over time. More research is also needed on how different forms of the program impact outcomes, for example, differences between online interventions and physical group meetings. In many countries, the public sector is 
struggling with high rates of sick leave, and it is important to know whether this program's preventive measures aimed at reducing risk factors could contribute to reduced sick rates.

The further development of a digital, web-based program of the theoretical framework proposed in this article, could provide an improved learning environment, with the benefits including ease of use, and save and load options [85], which may cater more appropriately to the daily time-pressured work situations of managers. This could further facilitate daily integration of evidence-based knowledge on handling and improving employee health. However, our results suggest that the managers prioritized coming to intervention meetings, as discussions with other managers provided inspiration and support for their own development work. A web-based program could thus be complemented with teams or groups of managers jointly working with, and reflecting on the development of health-promotive and sustainable leadership. This is in line with Bronfenbrenner (2000) who highlighted that for interventions and interactions to have better impact, they must occur repeatedly, or even regularly over time (the chrono-system perspective) [86].

\section{Conclusions}

This article has presented a comprehensive theoretical framework for health promoting managerial work that supports capability to craft sustainable psychosocial work conditions in daily practice and during change. The leadership program, related to the theoretical framework, aims to support impact in practice, through focusing on more sustainable and health-promoting leadership, that relies on a greater use of reflexive assessments of the psychosocial risk management process, instead of traditional regulation approaches. The development of sustainable working conditions, in practice, requires reflective management processes that manages the interactions between different levels in a work system, as these interactions have importance for function, well-being, and capability within all levels (individual, group, and organization) [35,37,67]. The key pedagogical principles of dialog and exercises aim to support and strengthen such proactive handling through reflective management processes, to keep a focus on resources, and supporting the adaptation and application of the program's evidence-based knowledge to practice.

Author Contributions: Lotta Dellve designed the theoretical framework and performed the literature reviews. Andrea Eriksson was responsible for performing the intervention and the evaluation study. Both wrote substantial sections of the paper and revised critically.

Conflicts of Interest: The authors declare no conflict of interest.

\section{References}

1. Pollitt, C.; Bouckaert, G. Public Management Reform: A Comparative Analysis; New Public Management, Governance, and the Neo-Weberian State; Oxford University Press: Oxford, UK, 2011.

2. Arbetsmiljöverket. Arbetsmiljöstatistik Rapport [In English: Report of Work Environment Statistics]; Arbetsmiljöverket: Stockholm, Sweden, 2016.

3. SBU. Arbetsmiljöns Betydelse för Symtom på Depression och Utmattningssyndrom [In English: The Importance of the Work Environment for Depression Symptoms and Burnout]; SBU: Stockholm, Sweden, 2014.

4. Vingård, E. En kunskapssammanställning: Psykisk Ohälsa, Arbetsliv och Sjukfrånvaro [In English: A Knowledge Review: Mental Ill Health, Working Life and Sick Leave]; FORTE: Stockholm, Sweden, 2015.

5. Nieuwenhuijsen, K.; Bruinvels, D.; Frings-Dresen, M. Psychosocial work environment and stress-related disorders, a systematic review. Occup. Med. 2010, 60, 277-286. [CrossRef] [PubMed]

6. González, R.; Cockburn, W.; Irastorza, X.; Houtman, I.; Bakhuys Roozeboom, M. European Survey of Enterprises on New and Emerging Risks Managing Safety and Health at Work; European Agency for Safety and Health at Work, Esener, European Union: Brussels, Belgium, 2010.

7. Orvik, A.; Axelsson, R. Organizational health in health organizations: Towards a conceptualization. Scand. J. Caring Sci. 2012, 26, 796-802. [CrossRef] [PubMed] 
8. Westgaard, R.H.; Winkel, J. Occupational musculoskeletal and mental health: Significance of rationalization and opportunities to create sustainable production systems-A systematic review. Appl. Ergon. 2011, 42, 261-296. [CrossRef] [PubMed]

9. Kira, M.; van Eijnatten, F.M. Socially Sustainable Work Organizations: Conceptual Contributions and Worldviews. Syst. Res. Behav. Sci. 2011, 28, 418-421. [CrossRef]

10. Parker, S.K. Beyond motivation: Job and work design for development, health, ambidexterity, and more. Annu. Rev. Psychol. 2014, 65, 661-691. [CrossRef] [PubMed]

11. Skakon, J.; Nielsen, K.; Borg, W.; Guzman, J. Are leaders well-being behaviors and style associated with the affective wellbeing of their employees? Work Stress 2010, 24, 107-139. [CrossRef]

12. Kelloway, K.; Teed, M.; Kelley, E. The psychosocial environment: Towards an agenda for research. Int. J. Workplace Health Manag. 2008, 1, 50-64. [CrossRef]

13. Dellve, L.; Skagert, K.; Vilhelmsson, R. Leadership in workplace health promotion projects: 1- and 2-year effect on long-term work attendance. Eur. J. Public Health 2007, 17, 471-476. [CrossRef] [PubMed]

14. Schaufeli, W.B.; Taris, T. A Critical Review of the Job Demands-Resources Model: Implications for Improving Work and Health. In Bridging Occupational, Organizational and Public Health: A Transdisciplinary Approach; Bauer, G.F., Hammig, O., Eds.; Springer: Berlin, Germany, 2014; pp. 43-68.

15. Schütte, S.; Chastang, J.F.; Malard, L.; Parent-Thirion, A.; Vermeylen, G.; Niedhammer, I. Psychosocial working conditions and psychological well-being among employees in 34 European countries. Int. Arch. Occup. Environ. Health 2014, 87, 897-907. [CrossRef] [PubMed]

16. Holmgren, K.; Hensing, G.; Dellve, L. The association between poor organizational climate and high work commitments, and sickness absence in a general population of women and men. J. Occup. Environ. Med. 2010, 52, 1179-1185. [CrossRef] [PubMed]

17. Dellve, L.; Wikström, E. Managing complex workplace stress in health care organisations: Leaders' perceived legitimacy conflicts. J. Nurs. Manag. 2009, 17, 931-941. [CrossRef] [PubMed]

18. Wikström, E.; Dellve, L. Contemporary Leadership in Healthcare Organizations: Fragmented or Concurrent Leadership and Desired Support. J. Health Organ. Manag. 2009, 23, 411-428. [CrossRef] [PubMed]

19. Wallin, L.; Pousette, A.; Dellve, L. Span of control and the significance for public sector managers' job demands: A multilevel study. Econ. Ind. Democr. 2013, 35, 455-481. [CrossRef]

20. Bronfenbrenner, U. Environments in developmental perspective: Theoretical and operational models. In Measuring Environment across the Life Span: Emerging Methods and Concepts; Friedman, S., Wachs, T., Eds.; American Psychological Association Press: Washington, DC, USA, 1999; pp. 3-28.

21. Carayon, P. Human factors of complex sociotechnical systems. Appl. Ergon. 2006, 37, 525-535. [CrossRef] [PubMed]

22. Rugulies, R.; Aust, B.; Syme, S.L. Epidemiology of health and illness: A socio-psycho-physiological perspective. In The Sage Handbook of Health Psychology; SAGE Publications Inc.: New York, NY, USA, 2004; Volume 27.

23. Bone, K.D. The Bioecological Model: Applications in holistic workplace well-being management. Int. J. Workplace Health Manag. 2015, 8, 256-271. [CrossRef]

24. Tengblad, S. (Ed.) The Work of Managers, towards a Practice Theory of Management; Oxford University Press: New York, NY, USA, 2012.

25. Tengblad, S. Management Practice-The doing of management. In the Oxford Handbook of Management (Chapter 16); Wilkinson, A., Armstrong, S.J., Lounsbury, M., Eds.; Oxford University Press: Oxford, UK, 2017.

26. Eriksson-Zetterquist, U.; Müllern, U.; Styhre, A. Organization Theory: A Practice-Based Approach; Oxford University Press: Oxford, UK, 2011.

27. Eriksson, A.; Axelsson, R.; Bihari Axelsson, S. Development of health promoting leadership-experiences of a training programme. Health Educ. 2010, 110, 109-124. [CrossRef]

28. Eriksson, A.; Skagert, K.; Dellve, L. Utveckling av Hälsofrämjande Ledarskap och Medarbetarskap [Development of Health Promoting Leadership and Employeeship]; Socialmed Tidskrift: Solna, Sweden, 2013; Volume 90.

29. Arman, R.; Wikström, E.; Tengelin, E.; Dellve, L. Work activities and stress among managers in health care. In The Work of Managers; Tengblad, S., Ed.; Oxford University Press: Oxford, UK, 2012.

30. Skagert, K.; Dellve, L.; Eklöf, M.; Ljung, T.; Pousette, A.; Ahlborg, G., Jr. Leadership and stress in public human service organizations: Acting shock absorber and sustaining own integrity. Appl. Ergon. 2008, 39, 803-811. [CrossRef] [PubMed] 
31. Skagert, K.; Dellve, L.; Ahlborg, G., Jr. A prospective study of managers' turnover and health in a healthcare organization. J. Nurs. Manag. 2012, 20, 889-899. [CrossRef] [PubMed]

32. Dellve, L.; Jacobsson, C.; Wramsten, W.M. Open, transparent management and the media: The managers' perspectives. J. Hosp. Adm. 2017, 6, 1-9. [CrossRef]

33. Lawrence, T.; Suddaby, R.; Leca, B. Institutional work: Refocusing institutional studies of organization. J. Manag. Inq. 2011, 20, 52-58. [CrossRef]

34. Barley, S.R.; Kunda, G. Bringing work back in. Organ. Sci. 2001, 12, 76-95. [CrossRef]

35. Dellve, L.; Andreasson, J.; Eriksson, A.; Strömgren, M.; Williamsson, A. Nyorientering av Svensk Sjukvård: Verksamhetstjänande Implementeringslogiker Bygger mer Hållbart Engagemang och Utveckling—I Praktiken. [Re-Orientation of Swedish Healthcare: Servant and Practice Oriented Management Approaches Builds Sustainable Engagement and Developments]; TRITA-STH-PUB: Stockholm, Sweden, 2016.

36. Czarniawska, B. En Teori om Organisering. [In English: A Theory on Organizing]; Studentlitteratur: Lund, Sweden, 2005.

37. Andreasson, J.; Eriksson, A.; Dellve, L. Health care managers' views on and approaches to implementing models for improving care processes. J. Nurs. Manag. 2016, 24, 219-227. [CrossRef] [PubMed]

38. Dellve, L.; Andreasson, J.; Jutengren, G. Hur kan Stödresurser Understödja Hållbart Ledarskap Bland Chefer $i$ Vården? [In English: How Can Support Resources Aid Sustainable Leadership among Managers in Health Care?]; Socialmedicinsk Tidskrift: Solna, Sweden, 2013; Volume 90, pp. 6-877.

39. Kira, M.; van Eijnatten, F.M.; Balkin, D.B. Crafting sustainable work: Development of personal resources. J. Organ. Chang. Manag. 2010, 23, 616-632. [CrossRef]

40. Antonovsky, A. Unravelling the Mystery of Health, How People Manage Stress and Stay Well; Jossey Bass: San Francisco, CA, USA, 1987.

41. Ryff, C.D.; Singer, B.H.; Love, G.D. Positive health: Connecting well-being with biology. Philos. Trans. R. Soc. Lond. B Biol. Sci. 2004, 359, 1383-1394. [CrossRef] [PubMed]

42. Nordenfelt, L. Quality of Life, Health and Happiness; Avebury: Arlington, VA, USA, 1993.

43. Galvin, K.T.; Todres, L. Kinds of well-being: A conceptual framework that provides direction for caring. Int. J. Qual. Stud. Health Wellbeing 2011, 6, 10362. [CrossRef] [PubMed]

44. Schulte, P.; Vainio, H. Well-being at work-Overview and perspective. Scand. J. Work Environ. Health 2010, 36, 422-429. [CrossRef] [PubMed]

45. Bakker, A.B. An evidence-based model of work engagement. Curr. Dir. Psychol. Sci. 2011, 20, $265-269$. [CrossRef]

46. Schaufeli, W.B.; Taris, T.W.; van Rhenen, W. Workaholism, burnout and engagement. Three of a kind or three different kinds of employee well-being. Appl. Psychol. 2008, 57, 173-203. [CrossRef]

47. Abdelhadi, N.; Drach-Zahavy, A. Promoting patient care: Work engagement as a mediator between ward service climate and patient-centred care. J. Adv. Nurs. 2012, 68, 1276-1287. [CrossRef] [PubMed]

48. Demerouti, E. Strategies used by individuals to prevent burnout. Eur. J. Clin. Investig. 2015, 45, 1106-1112. [CrossRef] [PubMed]

49. Nilsson, P. Enhance your Workplace. A Dialogue Tool for Workplace Promotion with a Salutogenic Approach. Ph.D. Thesis, University of Lund, Lund, Sweden, 2010.

50. Tengelin, E.; Arman, R.; Wikström, E.; Dellve, L. Regulating time commitments in healthcare organizations-Managers' boundary approaches at work and in life. J. Health Organ. Manag. 2011, 25, 578-599. [CrossRef] [PubMed]

51. Tengelin, E. Creating Proactive Boundary Awareness-Observations and Feedback on Lower Level Health Care Managers' Time Commitments and Stress. Licentiate Thesis, University of Gothenburg, Gothenburg, Sweden, 2012.

52. Ledarskap $i$ Äldreomsorgen: Att Leda Integrerat Värdeskapande $i$ en röra av Värden och Förutsättningar [In English: To Lead by Integrated and Value Adding Approaches in a Mess of Values and Pre-Conditions]; Dellve, L., Wolmesjö, M., Eds.; Vetenskap för Profession; Univeristy of Borås: Borås, Sweden, 2016; p. 35.

53. Strömgren, M.; Eriksson, A.; Bergman, D.; Dellve, L. Social capital among healthcare professionals: A prospective study of its importance for job satisfaction, work engagement and engagement in clinical improvements. Int. J. Nurs. Stud. 2016, 53, 116-125. [CrossRef] [PubMed]

54. Tims, M.; Bakker, A.B. Job crafting: Towards a new model of individual job redesign. SA J. Ind. Psychol. 2010, 36, 1-9. [CrossRef] 
55. Grant, A.M. Relational job design and the motivation to make a prosocial difference. Acad. Manag. Rev. 2007, 32, 393-417. [CrossRef]

56. Dellve, L.; Skagert, K.; Eklöf, M. The impact of systematic health \& safety management for occupational disorders and work ability. Soc. Sci. Med. 2008, 67, 965-970. [PubMed]

57. Dellve, L.; Fallman, S.L.; Ahlstrom, L. Return to work from long-term sick leave: A six-year prospective study of the importance of adjustment latitudes at work and home. Int. Arch. Occup. Environ. Health 2016, 89, 171-179. [CrossRef] [PubMed]

58. Barling, J.; Kelloway, E.K. Job insecurity and health: The moderating role of workplace control. Stress Med. 1996, 12, 253-259. [CrossRef]

59. Van Dierendonck, D. Servant leadership: A review and synthesis. J. Manag. 2011, 37, 1228-1261. [CrossRef]

60. Avolio, B.; Gardner, W.L.; Walumbwa, F.O.; Luthans, F.; May, D.R. Unlocking the mask: A look at the process by which authentic leaders impact follower attitudes and behaviors. Leadersh. Q. 2004, 15, 801-823. [CrossRef]

61. Avolio, B.J.; Walumbwa, F.O.; Weber, T.J. Leadership: Current theories, research, and future directions. Ann. Rev. Psychol. 2009, 60, 421-449. [CrossRef] [PubMed]

62. Losada, M.; Heaphy, E. The role of positivity and connectivity in the performance of business teams: A nonlinear dynamics model. Am. Behav. Sci. 2004, 47, 740-765. [CrossRef]

63. Gittell, J.H. High Performance Healthcare: Using the Power of Relationships to Achieve Quality, Efficiency and Resilience; McGraw Hill Professional: New York, NY, USA, 2009.

64. Nooteboom, B. Trust: Forms, Foundations, Functions, Failures and Figures; Edward Elgar Publishing: Cheltenham, UK, 2002.

65. Bell'e, N. Experimental evidence on the relationship between public service motivation and job performance. Public Adm. Rev. 2013, 73, 143-153. [CrossRef]

66. Helsing, D.; Drago-Severson, E.; Kegan, R.; Portnow, K.; Popp, N.; Broderick, M. Three Different Types of Change. Focus Basics 2001, 5, 10-14.

67. Eriksson, A.; Holden, R.J.; Williamsson, A.; Dellve, L. A Case Study of Three Swedish Hospitals' Strategies for Implementing Lean Production. Nord. J. Work. Life Stud. 2016, 6, 105-131. [CrossRef]

68. Watkins, K.E.; Lysø, I.H.; deMarrais, K. Evaluating executive leadership programs: A theory of change approach. ADHR 2011, 13, 208-239. [CrossRef]

69. Enos, M.D.; Kehrhahn, M.T.; Bell, A. Informal learning and the transfer of learning: How managers develop proficiency. Hum. Resour. Dev. Q. 2003, 14, 369-387. [CrossRef]

70. Mezirow, J. Transformative Dimensions of Adult Learning; Jossey-Bass: San Francisco, CA, USA, 1991.

71. Schön, D. Educating the Reflective Practitioner; Jossey-Bass: San Francisco, CA, USA, 1987.

72. Moon, S.; Birchall, D.; Williams, S.; Vrasidas, C. Developing design principles for an e-learning programme for SME managers to support accelerated learning at the workplace. JWL 2005, 17, 370-384. [CrossRef]

73. Kira, M. Routine-generating and regenerative workplace learning. Vocat. Learn. 2010, 3, 71-90. [CrossRef]

74. Newman, L. Uncertainty, innovation and dynamic sustainable development. SSPP 2005, 1, 25-31.

75. Wrzesniewski, A.; Dutton, J.E. Crafting a job: Revisioning employees as active crafters of their work. Acad. Manag. Rev. 2001, 26, 179-201.

76. Trader-Leigh, K.E. Case study: Identifying resistance in managing change. J. Organ. Chang. Manag. 2002, 15, 138-155. [CrossRef]

77. Feldman, M.S. Resources in emerging structures and processes of change. Organ. Sci. 2004, 15, $295-309$. [CrossRef]

78. Todnem By, R. Organisational change management: A critical review. J. Chang. Manag. 2005, 5, 369-380. [CrossRef]

79. Henning, R.; Warren, N.; Robertson, M.; Faghri, P.; Cherniack, M. Workplace health protection and promotion through participatory ergonomics: An integrated approach. Public Health Rep. 2009, 124, 26-35. [CrossRef] [PubMed]

80. Eklöf, M.; Pousette, A.; Dellve, L.; Skagert, K.; Ahlborg, G., Jr. Gothenburg Manager Stress Inventory (GMSI); [In English: Gothenburg Manager Stress Inventory (GMSI)]; Institutet för Stressmedicin: Gothenburg, Sweden, 2010. 
81. Eriksson, A.; Dellve, L.; Strömgren, M.; Edström Bard, E. Utveckling av Hållbart och Hälsofrämjande Ledarskap—I Vardag och Förändring. Utvärdering av Interaktiv Metodik för Företagshälsovårdsdrivna Interventioner. [In English: Development of Sustainable and Health-Promotiong Leadership -In Daily Practice and during Organizational Change]; TRITA-STH-PUB: Stockholm, Sweden, 2016.

82. Ovretveit, J. Evaluating Health Interventions: An Introduction to Evaluation of Health Treatments, Services, Policies and Organizational Interventions; McGraw-Hill International: New York, NY, USA, 1998.

83. Tynjälä, P.; Häkkinen, P. E-learning at work: Theoretical underpinnings and pedagogical challenges. JWL 2005, 17, 318-336. [CrossRef]

84. Ellström, E.; Ekholm, B.; Ellström, P.-E. Two types of learning environment: Enabling and constraining a study of care work. JWL 2008, 20, 84-97. [CrossRef]

85. Dias, S.B.; Diniz, J.A.; Hadjileontiadis, L.J. Towards an Intelligent Learning Management System under Blended Learning: Trends, Profiles and Modelling Perspectives. In Intelligent Systems Reference Library; Kacprzyk, J., Jain, L.C., Eds.; Springer-Verlag: Berlin/Heidelberg, Germany, 2014; p. 59.

86. Bronfenbrenner, U. Ecological systems theory. In Encyclopedia of Psychology; Kazdin, A., Ed.; Oxford University Press: New York, NY, USA, 2002; Volume 3, pp. 129-133.

(C) 2017 by the authors. Licensee MDPI, Basel, Switzerland. This article is an open access article distributed under the terms and conditions of the Creative Commons Attribution (CC BY) license (http:/ / creativecommons.org/licenses/by/4.0/). 